\title{
The Role of ECOWAS in the Fight against the Proliferation of Small Arms and Light Weapons in West-Africa Sub-Region
}

\author{
Osimen, Goddy Uwa ${ }^{1 *}$, Anegbode, E. John, Ph.D ${ }^{2}$, Isaac Adi, Ph.D ${ }^{3}$ \\ ${ }^{1}$ Department of Political Science \& International Relations Achievers University, Owo \\ ${ }^{2}$ Department of Political Science, Ambrose Alli University, Ekpoma, Edo State \\ ${ }^{3}$ Department of Criminology, Security \& Peace Studies, Caleb University, Lagos
}

*Corresponding Author: Osimen, Goddy Uwa, Department of Political Science \& International Relations Achievers University, Owo

\begin{abstract}
The conflict-ridden West African sub-region is a showcase of uncontrolled SALW proliferation. Vast quantities of arms have flooded the region despite their rampant misuse by state and non-state actors alike. The widespread availability of small arms to abusive actors poses a threat of unprecedented magnitude to West Africa, far greater than that of HIV/AIDS or Covid-19 in terms of its socio-economic and human consequences. Because of this proliferation, the fabric of the sub-region itself is rapidly changing, moving toward self-destruction. It is on this backdrop the paper examined the role of ECOWAS and its Convention in the Fight against SALW proliferation in the West Africa sub region. The paper revealed that, there are over one hundred million illicit SALW in West Africa, which has continue to fuel countless armed conflict in the sub region despite the un-relented efforts of ECOWAS to eradicate the menace in the sub region. The paper further revealed that ECOWAS Convention which seeks to combat the excessive and destabilizing accumulation of SALW within the sub region is nothing but a mirage as a result of weak national controls and lack of international cooperation on arms control that have led to the proliferation of these weapons on illicit markets. It was discovered that, the greatest barrier to resolving debates over gun policy in the sub region is the lack of comprehensive data and political will among the states. Hence, it concludes that, reducing SALW and the illicit transfer of weapons to combatants, criminals, and terrorists will require a fresh strategic approach with more defined objectives and greater commonality among the member states within the sub region. While the illicit proliferation of SALW presents one of the gravest security threats in modern times in the sub region, norms and frameworks, through ECOWAS such as the Programme of Action to regulate and prohibit the transfer, manufacture and possession of small arms and light weapons among unauthorized persons/organization will be welcome development but, such measures must be promoted through transparency, cooperation and exchange of information among member states.
\end{abstract}

Keywords: ECOWAS, Small Arms, Light Weapons, Proliferation, Sub Region, West Africa

\section{INTRODUCTION}

West Africa has for many years been the most unstable sub-region in the continent of Africa. Since 1975, of the 15 member states that make up the Economic Community of West African States (ECOWAS), there have been over 40 military coups, and 37 of which were successful including the 2020 (recent) coup in Mali. One causative factor for such unprecedented insurrection is the movement of small arms and light weapons (SALW) within the sub-region (Oxfam, 2016). The uncontrolled movement of SALW has exacerbated conflicts and brought destruction, untold hardship, poverty and underdevelopment (Francis, 2009). In 2006, the West Africa Action Network on Small Arms estimated that 8 million small arms and light weapons were transiting through the sub-region. The same year, the Heads of States of the Economic Community of West African States (ECOWAS) adopted a convention to regulate the production, circulation and civilian possession of small arms and light weapons as a collective measure against the phenomenon that drives much of the insecurity in West Africa.

SALW are extreme tools of violence in West Africa for several reasons. According to Small Arms Survey (2015), Small arms are durable, highly portable, easily concealed, simple to use, extremely lethal and possess legitimate military, police and civilian uses. In West Africa, these weapons are cheap and widely available; they are also lightweight, and so can be used by child soldiers, who have 
played such a significant role in recent conflicts in West Africa (Taylor, 2006). SALW therefore remain the primary weapons of intra- and inter-communal feuds, local wars, armed insurrections, armed rebel activities and terrorism throughout the sub-region. Every West African country has experienced widespread violence in which small arms featured. SALW have particularly fuelled overlapping and uncontained conflicts in Côte d'Ivoire, Guinea-Bissau, Liberia, Mali, Niger, Nigeria, Senegal, Sierra Leone and Togo, and the sub-region is still struggling to survive ongoing conflicts in which small arms play a central and destabilizing role (Small Arms Survey, 2013). According to Oxfam, (2016), Millions of West Africans have been killed or displaced as a result, and an immeasurable amount of property has been destroyed. SALW have been used to grossly violate human rights, to facilitate the practice of bad governance, to subvert constitutions, to carry out coups d'état and to create and maintain a general state of fear, insecurity and instability in the sub region. They are also being employed for non-political and non-conflict-related crime and violence. The true magnitudes of the problems caused by SALW proliferation in West Africa cannot be accurately quantified, as so many of the effects are hard to measure; such as fear and want. However, there is no dispute that small arms have had a devastating effect on development, governance and everyday life for West Africans. The porous nature of West Africa's borders plays a significant role in proliferation. Unmanned border crossing points and widespread corruption facilitate illicit trafficking in small arms. Despite the ending of many conflicts in the sub region, smuggling and the illicit trade in small arms are reported to be on the increase. Proliferation has also been facilitated by legal means. During conflict, some states in West Africa have liberalized gun possession laws in order to stimulate civilian arming. Arms were directly distributed to paramilitary groups by governments in order to fight rebel forces during the civil wars in Côte d'Ivoire, Liberia and Sierra Leone, but legislation was also liberalized, and proved a major driver of small arms diffusion. The fragmentation of the political and economic space in West Africa has shaped the availability and circulation of SALW. (Francis, 2009). The deterioration of many West African states' capacity to enforce the rule of law has blurred the boundaries between legal and illicit markets, enabling a thriving trade in SALW. Politicians have even been known to acquire weapons from illegal dealers to arm security personnel during election season.

The fight against the proliferation of small arms and light weapons is a key priority on West Africa's peace and security agenda. Stopping the illegal circulation and proliferation of small arms and light weapons is such an important objective that the Economic Community of West African States (ECOWAS) stand for. The mechanism for conflict prevention, management, resolution, peacekeeping and security devotes under article (article 51) specifically established for "Preventive Measures against the Illegal Circulation of Small Arms (ECOWAS Convention, 2006). This says that "ECOWAS shall take all the necessary measures to combat illicit trafficking and circulation of small arms in the sub region (Anatole and Ibrahima, 2005). The growing awareness of the interconnectedness of the threats to security and of the need for a holistic approach to building security has also led to the adoption of key instruments at the sub-regional level in the fields of prevention of conflict, human trafficking and drug trafficking.

Of course, SALW violence is not only confined to zones of formal armed conflict. Its fatal consequences can be traced to other contexts where demographics, social customs, unemployment, and varying levels of development explain motivations for SALW misuse in interpersonal violence, gang warfare, and organized crime (Small Arms Survey,2013). Alarmingly, of the estimated global fatalities resulting from the use of firearms, over two-thirds are attributed to criminal activities and violence in non-conflict settings Keith, (2007). Additionally, the adverse effects of SALW are not limited to physical injury and fatality; the socioeconomic costs of SALW violence are also high. These costs include medical expenses, nonmedical costs (i.e., policing and postconflict reconstruction), and the loss of productivity and private investment. According to a study by the InterAmerican Development Bank and UN Institute for Disarmament Research, the direct and indirect costs of violence in West Africa, for instance, amount to 14.2 percent of the region's aggregate gross domestic product per year (UNIDR, 2006).

However, crises provide unparalleled opportunities for change. These moments are transitory, but they need to be seized upon to put ideas into action, to strengthen the capacity to meet the challenges we face, which in today's globalizing world means more responsive, effective, and efficient multilateral mechanisms and policies. In response to these challenges, ECOWAS policy on tracing of 
illicit Small Arms and light Weapons is a key mechanism for national and regional efforts to prevent, combat and eradicate illicit circulation, trafficking and proliferation of SALW. The ECOWAS Commission is committed to strengthening the ability of its Member States to cooperate in identifying and tracing illicit SALW in a timely and reliable manner. Though, the ECOWAS policy has been faced with the problem of implementation. It rapidly became clear in 1999 that there was substantial confusion about the terms of the Moratorium. In several ECOWAS countries, the military and the arms transfer licensing authorities were apparently unaware that their government had declared the Moratorium. A recent studies on small arms and light weapons indicates that underpinning these proliferation were bad governance, high levels of poverty, struggle for scarce resources, and the competition for economic and/or political power among the elites, oil theft, money laundering, corruption, exploitation, terrorism, militancy, ethno-religious violence, scrambling for resource control, and other premeditated violence (Ibrahim, 2015: 5; Small Arms Survey, 2015; Onuoha, 2013; Osimen and Akintunde, 2015).

Therefore, the problem for this paper is to identify the fundamental problems associated with small arms and light weapons, from misconceptions, to their magnitude, modes of acquisition, consequences and challenges with emphases on the role of ECOWAS in controlling small arms and light weapons proliferations in the sub region. The objectives of this paper shall be to provide answers to the following questions; what are the current efforts and institutional policies of ECOWAS in sub regional capacity in illicit use of SALW? Why are some of the previous attempts to address the menace failed? What policies and institutional renovations, including legal frameworks and financial arrangements, are needed to succeed in this course? What strategy is needed to achieve these renovations? These and more will form the framework of this paper.

\section{CONCEPTUAlization OF TERMS}

Small arms proliferation is a related term used to describe the growth in both the authorized and the illicit markets. Users of the term have notably included Kofi Annan an ex-Secretary-General of the UN. The small arms market includes legal and illegal transfers (Kofi, 2010). Legal transfers are generally defined as those approved by the involved governments and in accord with national and international law. Black market (illegal) transfers clearly violate either national or international law and take place without official government authorization.

What are small arms and light weapons? There is no universally accepted definition of a 'small arm' or of a 'light weapon'. The Small Arms Survey uses the term 'small arms and light weapons' to cover military-style small arms and light weapons as well as commercial firearms (handguns and long guns). The UN program does not really define small arms or light weapons, but they are usually understood as:

According to the UN, small arms and light weapons are weapons that can be transported and used by one person or a small crew. Small arms are revolvers and self-loading pistols, rifles and carbines, assault rifles, sub-machine guns, and light machine guns. Light weapons are heavy machine guns, hand-held under barrel and mounted grenade launchers, portable antitank and anti-aircraft guns, recoilless rifles, portable launchers of anti-tank and anti-aircraft missile systems, and mortars with calibers of less than 100 millimeters (UNGA, 2005). According toUN Institute for Disarmament Research "a subcategory of conventional arms that includes firearms and other small arms, such as pistols, revolvers, and assault rifles, as well as light weapons such as heavy machine guns, man-portable air defense systems, and howitzers with calibers of less than 100 millimeters." UNIDR, (2006)

One of the most widely accepted definitions comes from the 1997 report of the United Nations Panel of Governmental Experts on Small Arms. In general terms:

'small arms' are designed for personal use and may be carried by one person; 'light weapons' are used by several persons or a crew and may be transported by two or more people, a pack animal, or a light vehicle (UNGA, 2005a, paras. 25, 27a)). The International Tracing Instrument provides the following definition of small arms and light weapons:

According to Small Arms Survey 2001:

"any man-portable lethal weapon that expels or launches, is designed to expel or launch, or may be readily converted to expel or launch a shot, bullet or projectile by the action of an 
explosive, excluding antique small arms and light weapons or their replicas (UNGA, 2005b,, It then goes on to note that, broadly speaking, small arms are 'weapons designed for individual use' and light weapons are 'weapons designed for use by two orthree persons serving as a crew, although some may be carried and used by a single person' (UNGA, 2005b). It subsequently repeats the list of examples provided in the 1997 UN Panel report"

What are firearms? A legally binding definition of 'firearm' is contained in the Firearms Protocol (see Part 2.1), which provides:

'Firearm' shall mean any portable barreled weapon that expels, is designed to expel or may be readily converted to expel a shot, bullet or projectile by the action of an explosive, excluding antique firearms or their replicas. Antique firearms and their replicas shall be defined in accordance with domestic law. In no case, however, shall antique firearms include firearms manufactured after 1899 (UNGA, 2005c, art. 3(a)).

According to ECOWAS Convention definition:

'Small arms' refers to arms used by one person, and which include firearms and other destructive arms or devices such as exploding bombs, incendiary bombs or gas bombs, grenades, rocket launchers, missiles, missile systems or landmines; revolvers and pistols with automatic loading; rifles and carbines; machine guns; assault rifles; and light machine guns. 'Light weapons' are portable arms designed to be used by several persons working together in a team, and which include heavy machine guns, portable grenade launchers, mobile or mounted portable anti-aircraft cannons; portable anti-tank cannons, non-recoil guns; portable anti-tank missile launchers or rocket launchers; portable anti-aircraft missile launchers; and mortars with a calibre of less than 100 millimeters.

In this paper, the terms 'small arm' is more commonly used to refer to the weapon an individual may use and carry in a military context.

\subsection{Sources of Arms and Weapons Supply in West Africa Sub Region}

Diversion from state stockpiles: The diversion of legally acquired arms by African countries is a common source of uncontrolled and illicit arms. This can occur in several forms, including the illegal sale of official arms by corrupt officials to non-state actors. According to PM News (10 February 2016) For example, some Nigerian soldiers were arrested in February 2016 for illegally selling arms to Boko Haram members. The diversion of state arms stockpiles is also facilitated by the poor welfare conditions of uniformed personnel, weak governance and a lack of oversight over arms procurement and accountability of weapons stockpiles. Soldiers in most African countries are underpaid, and their salaries are often delayed for several months. This has reportedly led to riots, sexual violence, looting and involvement in corrupt practices, as has been reported in the DRC, Burkina Faso, Mali, and Guinea.

Black markets and illicit trading: The number of conflicts in Africa illustrates the thriving scope of the illicit arms trade in the continent. Locally-made arms and diverted stocks are traded in parallel arms markets. In 2013, Cameroonian security forces arrested a man who was transporting 655 guns to Nigeria, and another 5,400 AK-47 rifles were intercepted in Maroua, in the northern region of Cameroon (Oxfam, 2016). Based on the Small Arms Survey assessment of Libya's illicit arms market, SALW such as heavy machine guns, shoulder-fired recoilless weapons, rocket launchers, anti-tank guided missiles, man-portable air defence systems, grenade launchers, and different types of rifles can be bought online (Small Arms Survey, 2016).

Local arms production: In the 1970s and early 1980s, local arms production did not receive enough attention in Arica. Arms manufactured locally were mostly used for hunting and for traditional rites. However, the rise in the use of firearms for violent crime suggests that locally produced arms have become a sound and cheap alternative to imported weapons. Several unauthorized local arms producers exist across Africa, and the limited regulation of their activities contributes to the ready availability of SALW. In Ghana for instance, as of 2005, local gunsmiths have the capacity to produce over 200,000 weapons annually, including pistols, single and double barrel guns, traditional dane guns, and pump-action shotguns. Over 60 percent of illegal arms in southeast Nigeria are locally made (Nwaiwu, 2015). In Mali, locally made weapons are widespread, and are used to commit crimes. This 
led to the enactment of law 040-50/ANLM to regulate the manufacture, use and trade in locally made weapons, and the promulgation of decree 05-441/P-RM for the enforcement of the law.

Arms trafficking and Smuggling: Weapons are circulating at all levels from the smuggling of individual weapons to large shipments. Article 2 of the draft International Firearms Protocol defines illicit firearms trafficking as:

"the importing, exporting, acquisition, sale, delivery and movement or transfer of firearms, their parts and components and ammunition from or across the territory of one State Party to that of another State party without the authorization of or in violation of the legislation or regulations of any one of the State parties concerned"Owen, (2000).

According to Owen (2000), trafficking consists of higher value or more difficult illicit shipments of arms that often involve corrupt officials, brokers or 'middle-men' motivated mainly by profit Owen, (2000). These often use well-established networks and channels also employed for smuggling other illicit goods. Recent research assessing the border threat, noted the patterns of arrival and circulation of small arms within the Mano River Union (Guinea, Liberia and Sierra Leone). Communities interviewed disclosed that during the civil wars in Liberia and Sierra Leone, illicit trade in small arms and light weapons, particularly AK- 47s, RPGs, FM light machine guns, M16 rifles, two-barrel Berettas, pistols, bazookas and mortars, increased along the KoinaduguKailahun axis of Sierra Leone. Some of these arms and ammunition are still being trafficked into Sierra Leone from Guinea and Liberia and vice versa. The assessment report identified the Guinea Forest and the Parrot Beak regions as the most prominent routes for trafficking arms within the Mano River Basin. The borders between West Africa's states are long and full of footpaths, which are poorly patrolled (Owen, 2000). More than 150 illegal crossing points were identified to and from Sierra Leone and Guinea and Liberia. Over $85 \%$ of crossing points were covered by fewer than $11 \%$ of the customs, immigration and security officials identified. The Sierra Leone Border Threat Assessment Report established that smuggling of SALW can be a real threat to stability in the Mano River Basin (Taylor, 2006). In mid2003, while conflict raged in Liberia, the government of Guinea imported mortar rounds and other ammunition from Iran. These were declared on cargo documents as "detergent" and "technical equipment. From Guinea, the weapons were forwarded to allied rebels inside Liberia who had just launched two offences on the capital, Monrovia. The rebels of Liberians United for Reconciliation and Democracy used these weapons to fire indiscriminately on civilian areas of Monrovia.

\subsection{The Impact of Small Arms and Light Weapons in West Africa}

SALW have escalated the intensity and impacts intra-state armed conflicts in West Africa. They are responsible for the majority of direct conflict deaths in West Africa as evident in the civil wars in Côte d'Ivoire, Liberia and Sierra Leone, and play a central role in the many thousands of indirect conflict deaths caused by loss of access to health services, forced displacement. According to Africa Council for Religions Leaders (2006), Small arms and light weapons are the primary tools of violence, causing deaths and injuring thousands of people, among the innocent civilians (Frankonero, 2008). It has promoted widespread of insecurity and hamper the provision of social services such as in the areas of health and education, and access to food and water in the sub region. Insecurity impedes long-term socio-economic development by forcing people to move, leaving their harvests and businesses unattended. It has also diverts public spending away from key sectors of development such as health, agriculture, engineering and education in the sub region. Most deaths recorded in conflict and security-challenged environments in the continent are caused by SALW. For example, an estimated 1,689 to 3,713 were killed between 2012 and 2014 in Mali alone. Most of these deaths were civilians killed by rebels and other armed groups. And up to August in 2016, 902 deaths have been recorded. While the figures of deaths in recent years are dwarfed by the estimated 50,000 fatalities in 2011 the huge arsenals of uncontrolled arms in the possession of non-state armed groups, and increasing reports of clashes with pro-government forces, suggests that unarmed civilians will continue to be victims of uncontrolled arms in the region Oxfam (2016). SALW significantly undermine the human rights of civilians in the areas where they are prevalent.

Beyond the numbers, killings involving illicit arms are horrific and psychologically devastating to victims and their relatives. For example, Seydou, 34 years old, lost his parents to heavily armed bandits who shot them and looted their home in northern Mali.The plight of refugees must be taken 
into account in the sub region; the lost productivity as refugees are forced to live in camps and become dependent on humanitarian aid, and the immeasurable psychological trauma they go through for instance, statistics from UNHCR show that more than 134,000 Malian refugees are in neighbouring Mauritania, Burkina Faso and Niger, and over 36,000 are internally displaced (UNHCR, 2017). The civil war in Sierra Leone for instance, where SALW were the main engine of violence, saw over 50,000 people killed, 30,000 had their limbs amputated, and 215,000-257,000 women were victims of sexual violence (Francis, 2009). During conflict, the structures of SALW circulation have integrated into economic structures. SALW have an economic value to the fighters that receive them; they enable combatants to engage in predatory violence against civilian populations, stealing goods to sell on the local black market, which is the easily accessible illicit medium of transaction, for personal sustenance and enrichment. In some sub-regional conflicts, such "bottom-up" war economies have generated a degree of informal cooperation between the combatants of governments and insurgent forces that has sometimes included the trading of SALW. Thus in Sierra Leone, in a new form of cooperative predation, government forces would withdraw from a town, leaving SALW behind. The RUF rebels would take control, collect the arms, and extract cash from the civilian population before retreating. Government forces would then reoccupy the town, looting property that the rebels found more difficult to sell, and engage in illegal mining. SALW have been called "weapons of mass destruction" in West Africa with good reason. The availability of SALW in West Africa has longterm and widespread pernicious effects. Even when conflicts have been officially terminated, small arms have remained, illicitly, in the post-conflict zones of Liberia, Mali, Niger, Senegal and Sierra Leone, making it easy for fighting to recommence. Even when further combat is avoided, the easy availability of small arms means that they have become common tools of violence, used in criminal activities and ethnic and political rivalries. Armed combatants may become affiliated with local gangs, warlords or militias. This enduring climate of violence has often resulted in refugees and displaced persons fearing to return home after a conflict have ended. The insidious nature and impact of these weapons affects all aspects of society. Small arms, especially firearms, are the primary tools used to kill, threaten and intimidate civilian populations in West Africa. Small arms play a significant role in many abuses, including rape, enforced disappearances, torture, forced displacement and enforced recruitment of child soldiers. When crimes have been committed with machetes, the victims were often initially rounded up with small arms. Heavily armed individuals create an environment in which atrocities can be committed at will and with impunity. Even small numbers of small arms confer great power on those that bear them. It is estimated that more than $50 \%$ of the weapons that proliferate in Africa are used illicitly in trafficking, armed robbery, terrorism and organized crime. According to Africa Council for Religions Leaders (2006), the proliferation of small arms has also encouraged fear in countries where the state uses small arms to quell political opposition. In Nigeria, the country's oil-rich Delta State has seen conflict since 2003 involving well-armed militia groups motivated in part by economic interest in stolen crude oil. These groups use a range of sophisticated weapons, such as semi- and fully automatic rifles, alongside more traditional weapons to carry out deadly and paralysing attacks on oil and gas installations. They have killed scores of security officials, damaged oil facilities and infrastructure, and shut down oil production. They have also taken for eign oil workers hostage. Hundreds of people have been killed in the violence, which has also resulted in the displacement of thousands and the destruction of hundreds of properties. Just as the movement of fighters ready to bear arms aids proliferation, it is a result of small arms proliferation, as their supply creates the demand for people to bear arms. Equally, SALW fuel the illicit trafficking of natural resources such as oil, diamonds, timber and coffee. This is in part due to the porous nature of the borders in West Africa, which exposes the countries to a number of interrelated threats, including smuggling, robbery, dissident activities, and rebellion and cross-border raids. All of these are facilitated by the possession and use of small arms. The impact of SALW on economic well-being and national development in West Africa is of vast significance (Francis, 2009).Most victims of small arms violence in West Africa are young men, who have the highest earning potential. Non-fatal injuries, which are far more numerous than deaths, involve both costs to productivity and the expenses of health care. These costs must in most cases be met by individuals, households and their communities. Women's burden of income generation and care giving has increased substantially with the death or injury of so many men. SALW have also placed women and girls at increased risk of severe injury or death. Levels of abuse and domestic violence have increased in post-conflict West African societies, as ex-combatants return home with arms, and these small arms are used to carry out 
sex crimes. Gender-based violence (GBV) is widespread in Africa, especially in conflict situations. It is estimated that about 45.6 percent of African women have experienced GBV, compared to 35 percent globally. It is estimated that most African women and girls will experience a form of GBV in their lifetime.In Mali, data from a 2014 USAID Fact Sheet shows 38 percent of women aged 15 and above have experienced physical violence, while more than 10 percent of women between 15 and 49 years have been sexually assaulted (ENCA 2013). The UN also recorded 90 allegations of conflictrelated sexual violence, 69 rapes and 21 sexual assaults in the region. In conflict situations, GBV is generally associated with armed groups and combatants, who use SALW to humiliate, intimidate, displace and traumatize individuals and communities. The presence of small arms creates an atmosphere of fear that affects the resumption of normal economic activity and everyday life. It prevents people from conducting business, leading to reduced trade and foreign investment; small arms violence, be it crime- or conflict-related, has had a particularly significant impact on tourism in West Africa. It also affects public services; the proliferation of small arms within the sub-region has inhibited access to basic services and key infrastructure, such as health clinics, schools and markets. There is a strong correlation between small arms violence and deteriorating public services in the subregion. Government services and aid programmes have to be curtailed or withdrawn because of insecurity. Levels of school enrolment and literacy have declined, as have immunizations, while child and maternal mortality have increased. Over time, this has represented a huge cumulative loss in productivity and wealth.

Finally,uncontrolled arms also play a significant role in the dislocation of communities. For instance, in Mali, a 35-year-old woman fled Timbuktu with her husband and four children, leaving her elderly parents and other relatives behind when Islamists took control of the ancient city. The imposition of Sharia law and its strict interpretation resulted in the destruction of many of the city's historical sites and cultural heritage. Punishments meted out by armed Islamists for disobedience included flogging, amputation and execution (Oxfam, 2016).

\subsection{The Significance Efforts by the ECOWAS to Combat the Proliferation of Small Arms}

ECOWAS member states consider the proliferation of small arms and light weapons to constitute a major threat to peace and stability within ECOWAS member states. Therefore, what measures have ECOWAS member states taken to counter the proliferation of small arms and light weapons in the sub region? Over the years, ECOWAS has made significant efforts to combat the proliferation of SALW in the sub region. Of all the sub-regional initiatives, ECOWAS has made the most dramatic strides toward curbing the illicit trade in small arms, with its unprecedented moratorium on the import or manufacture of small arms in the region. In June 2006, the ECOWAS secretariat approved a legally binding version of the moratorium after the West Africa Action Network on Small Arms, a regional nongovernmental organization assisted by the aid agency Oxfam, succeeded in developing acceptable treaty language" (Stohl, \&Myescough, 2007). The moratorium finally put into law among the ECOWAS countries began as an initiative by Mali in 1993. The aim of the moratorium has been widely applauded as it challenges the main aspects of the SALW trafficking that makes it difficult to stop. It calls for harmonized national controls among member states, supporting training programs for military, police, and security forces, enhanced border controls, stockpile management, and facilitating dialogue with arms supplier countries. As a result, the moratorium is seen as a plausible and effective means to end the trafficking of SALW (Frankonero, 2008). In few of the conventions, ECOWAS member states agreed to control, regulate and/or prohibit the transfer, manufacture and possession of small arms and light weapons. They also agree to take measures to promote transparency; cooperation and exchange of information among member states. They are deeply concerned about the flow of small arms and light weapons into West Africa and recognize the need to control arms transfers and to prevent, combat and eradicate the illicit manufacture, excessive accumulation, trafficking, detention and use of small arms and light weapons. In light of this, and recognizing the principles and obligations contained in previous agreements, member states agree to the articles contained in this convention.

The objective that ECOWAS has set for itself presupposes both "upstream" and "downstream" intervention, from the production and delivery of arms to their final use, from the international manufacturers to local owners and users. These, then, are the general principles set out in the Treaty of ECOWAS and in the 1999 Protocol relating to the Mechanism for Conflict Prevention, Management, 
Resolution, Peacekeeping and Security. Efforts to combat the proliferation of small arms are included among them, alongside the Community's other concerns. Provisions that deal exclusively with this problem, and that follow on from these two general instruments, can be found in other ECOWAS legal instruments, namely:

$>$ The Moratorium on the Importation, Exportation and Manufacture of Light Weapons in ECOWAS member states (referred to as simply the "Moratorium"), adopted on 31 October 1998;

$>$ The plan of action for implementation of the Programme for Coordination and Assistance for Security and Development in Africa (PCASED), adopted in 1998;

$>$ The code of conduct for the implementation of the Moratorium, adopted on 10 December 1999.

In further to deal with illicit of SALW in the sub region, ECOWAS advocate the establishment of a database and regional arms register; the ECOWAS aim here, particularly through the register (Cheikh, 2005), is to introduce a sort of "identity card" for weapons, by identifying them with a number in order to make them easier to trace, either when they are taken from one country to another or when they are sold or borrowed (Cheikh, 2005).

Majorly, the question of small arms is dealt with in particular in articles 50 and 51 of the Protocol relating to the Mechanism. Article 50, on "Control of the proliferation of small armsprovides as follows:

"While taking into account the legitimate national defence and security needs, and those of international peacekeeping operations, ECOWAS shall establish effective measures to: (a) Control the importation, exportation and manufacture of small arms and eradicate the illegal flow of such arms; (b) Register and control the movement and use of legitimate arms stocks; (c) Detect, collect and destroy all illicit weapons; (d) Encourage member States to collect and destroy all surplus weapons.ECOWAS Convention" (2006).

Article 51, on "Preventive measures against the illegal circulation of small arms", provides as follows:

"ECOWAS shall take all the necessary measures to combat illicit trafficking and circulation of small arms. These measures shall include:

(a) Developing a culture of peace; (b) Training for military, security and police forces; (c) Enhancing weapons control at border posts; (d) Establishment of a database and regional arms register; (e) Collection and destruction of [surplus and] illegal weapons; $(f)$ Facilitating dialogue with producers and suppliers; $(g)$ Reviewing and harmonizing national legislation and administrative procedures; (h) Mobilizing resources.ECOWAS Convention" (2006).

In an attemptto limit the number of weapons in circulation; according to ECOWAS Protocol, there are "legitimate" weapons and "illicit" weapons. The latter category refers to those that are manufactured or acquired unlawfully and are not needed for the legitimate purposes of national defence, and that lend themselves to unregulated proliferation and illicit circulation. The same ideas apply to "surplus weapons" (Cheikh, 2005). In addition, initiation of a dialogue or partnership with arms manufacturers or suppliers; this idea is to stem the flow of illicit weapons; such partnerships are not of course intended to close down the arms trade, but simply to introduce, through cooperation, a little more transparency in the sale and movement of arms.

The political will to control small arms and light weapons within the territory of ECOWAS has been forcefully expressed on many occasions by the Heads of State and Government, as shown by the various aforementioned political and legal decisions that have been adopted. The major challenge remains translating this will into practical action, which primary responsibility for which now lies, as in many areas of community policy, with the ECOWAS Commission, which has replaced the Executive Secretariat (Cyriaque, 2008).

\section{CONCLUSION AND RECOMMENDATIONS}

ECOWAS, as a sub-regional organization, does not currently have all the material resources to control the circulation of small arms within the member states. This is why, with a view to boosting the credibility of its objectives, the Protocol provides for the establishment of national commissions to 
implement and promote all these measures and to coordinate them with measures taken at the national level. These commissions are established by the Authority of Heads of State and Government in a decision adopted at the same time as the Protocol. They are described as national commissions to combat the proliferation and illicit circulation of small arms and consist of representatives of the ministries responsible for defence, the interior, security, justice, foreign affairs and civil society. Their role is to submit to the authorities all relevant proposals for combating the proliferation of small arms, undertake awareness-raising activities, cooperate and exchange experiences with the commissions from other member states, bring their work to the attention of bilateral or multilateral institutions, help the authorities to comply with their international obligations to combat the proliferation of small arms. Small arms control is a collective endeavour within the ECOWAS especially, with the adoption of the Declaration of a Moratorium on the Importation, Exportation and Manufacture of Small Arms and Light Weapons in West Africa by the Conference of Heads of State and Government in Abuja on 31 October 1998.

The adoption of the Code of Conduct confirms the ECOWAS Commission's role in carrying out, coordinating and monitoring implementation of the sub regional small arms control policy. The legal framework reflecting this policy, which is rooted in the spirit of the moratorium dating back to the adoption of the ECOWAS Convention on Small Arms and Light Weapons, Their Ammunition and Other Related Materials, will enshrine a number of principles and issues at the heart of the current international debate on an arms trade treaty and arms transfer control initiative. Therefore, Preventing illicit arms transfers requires the adoption of policies, procedures, and practices aimed at controlling their import, export, transit, retransfer, and end use. The misuse of SALW and the illicit transfer of weapons to combatants, criminals, and terrorists will require a fresh strategic approach with more defined objectives and greater commonality across the multilateral system.

$>$ However, if this policy is to be implemented effectively and efficiently, there will be need to put more effort in addition to the necessary technical and financial resources with adequate and functioning institutional arrangements in place at the national and sub-regional levels with the capacity to play their role in full. In this respect, the ECOWAS Commission, whichis the cornerstone of this arrangement, must strengthen its own institutional capacities while strongly supporting the institutionalization and operation of the national commissions of member states and the restructuring of civil society organizations working in this field.

$>$ Secondly, all countries within the sub region need to compliment ECOWAS efforts to fight against illicit use of SALW and harmonize their efforts in executing internal initiatives, as only appropriate governments understand their unique challenges and the necessary national response requirements.

$>$ Also, comprehensive implementation of the UN small arms instruments should remain a principal focus of further efforts to combat the proliferation and misuse of small arms effectively. Officials have to take steps to remedy any weaknesses in controls at their own national levels that facilitate and contribute to small arms diversions and the illicit small arms trade. States that have not yet done so need to review their national controls and their implementation in light of their commitments under the UN instruments on small arms. Where relevant, states should define a national strategy for ensuring their compliance with the UN instruments and the responsible management of small arms. The consensus-based proceedings under the UN program of action impose clear limits on what may be achieved at the global level in light of the current opposition by some states to the introduction of further standards to control the small arms trade.

$>$ In addition, government must rein- forces her political commitment to implementing the provisions of the Instrument of the UN to combat the illicit of Small Arms and Light Weapons. Establishing agencies to coordinate policy and research on the illicit small arms trade and identifying points of contact to liaise between these national agencies and UN is the most basic and the easiest to implement of the pillars.

$>$ Government must also, develop strategies that address the reasons why individuals, groups, and governments seek weapons in the first place. Such strategies must reflect an understanding of the complexities of violence in conflict zones, crime-ridden countries, and countries recovering from war and should involve government officials, local community leaders, and NGOs. These 
strategies must be linked to other aspects of violence-reduction and disarmament programs, such as security sector reform, and build them into existing programs, such as DDR programs, by providing populations with ways to achieve security and power other than through armed.

$>$ The Governments through multilateral and bilateral cooperation should also ensure cross-border cooperative measures within the neighbouring countries. Border must be effectively and properly managed and with other action that can stamp out cross-border crimes rather than, just empty gestures. The proliferation of light weapons occupies pride of place. Light weapons are widely used in African conflicts, in particular owing to their "advantages" they are cheap, easy to transport and conceal, simple to maintain and easy to handle. Therefore, Success in efforts to combat the proliferation of light weapons will largely depend on political will, as displayed in particular in cooperation between states

$>$ Furthermore, to ensure that weapons are used for lawful purposes, governments should establish domestic ownership licensing and authorization systems that take into consideration the applicant's history of violent behavior, mental health, age, and knowledge of the laws and the safe operation of weapons, among other criteria.

$>$ Internationally, the implementation and enforcement of national and international arms embargoes must be improved. Particularly important are UN arms embargoes, violations of which must be thoroughly investigated and punished by the international community. At the national level, those governments that lack authorization systems for the production and transfer of small arms and light weapons should establish them immediately, and countries with weak systems should take steps to strengthen them. Coordinating the work of these networks to combat the illegal circulation of small arms could substantially reduce the proliferation of such weapons. Only appropriate intelligence services can help in an effective way to identify the groups and individuals that are engaged in the manufacture, sale, storage, transfer, possession and illegal funding of this category of weapon. This will call for sophisticated intelligence equipment such as electronic communication facilities, scanners, digital fingerprinting machines, radios, computers and vehicles.

$>$ Finally, Road blocks should be seen as one of the efforts to combat the proliferation of small arms, constant road checks must be organized with the aim of apprehending the individuals being sought and preventing trafficking in arms and ammunition. For this purpose, road blocks should be set up on the main highways, secondary roads and even footpaths. The numbers of security personnel involved in these operations will depend on the number of roads to be covered and the volume of road traffic. Experience shows that road blocks constitute one of the most effective means of combating the proliferation of small arms at the national and regional levels.

\section{REFERENCES}

[1] Anatole, A. and Ibrahima, S. (2005), Combating the Proliferation of Small Arms and Light Weapons in West Africa: Handbook for the Training of Armed and Security Forces; UNIDIR Geneva, Switzerland.

[2] Cheikh O. D.(2005), ECOWAS as the Institutional Framework for Efforts to Combat the Proliferation of Arms in West Africa: Handbook for the Training of Armed and Security Forces; UNIDIR Geneva, Switzerland.

[3] Cyriaque, P. A. (2008), Political and institutional dynamics of the control of small arms and light weapons in West Africa; Printed at United Nations, Geneva GE.05-00859—January 2009 - 4,480 UNIDIR/2009/1 ISSN 1020-7287

[4] ECOWAS Convention on Small Arms, Light Weapons, (2006) their ammunition and other associated material', Economic Community of West African States (ECOWAS) http://www.poaiss.org/Regional Organizations/ECOWAS/ECOWAS\%20Convention\%202006.pdf

[5] ENCA (2013). Africa leads in gender-based violence, https://www.enca.com/africa/africaleads-genderbased-violence.

[6] Francis, L. K (2009) Small arms and light weapons transfer in West Africa: a stock-taking; the-complexdynamics-of-small-arms-in-west-Africa- Printed at United Nations, Geneva-January 2009 -4,480 UNID IR/2009/1 ISSN 1020-7287.

[7] Frankonero, N. (2008) Effects of Proliferation of Small Arms in Sub-Sahara Africa; USAWC Strategy Research Project

[8] Ibrahim, A. (2015), "Contextualizing the Proliferation of Small Arms and Light Weapons in Nigeria: The Untold Story", International Journal of Business and Law Research, Vol. 3 No. 1, pp. 1-14. 
The Role of ECOWAS in the Fight against the Proliferation of Small Arms and Light Weapons in WestAfrica Sub-Region

[9] Keith, K. (2007) "Small Arms and Light Weapons: Towards Global Public Policy," Coping with Crisis Working Paper Series (New York: International Peace Academy, March 2007), p. 3.

[10] Kofi, A.(2010), Millennium report to UN General Assembly (UNGA), New York, USA.

[11] Nwaiwu, C. (2015). 60\% of illegal arms in S/East produced locally - Presidential Committee, Vanguard. http://www.vanguardngr.com/2015/10/60-of-illegal-arms-in-seast-produced-locallypresidential-cttee/

[12] Onuoha, F. (2013), "Porous Borders and Boko Haram's Arms Smuggling Operations in Nigeria", Al Jazeera Center for Studies. 8 September, 2013.

[13] Osimen, G.U. and Akintunde, B.A. (2015), "Small Arms and Light Weapons (SALW) Proliferation and Problems of National Security in Nigeria", International Affairs and Global Strategy, Volume 29, 2015.

[14] Owen, G. (2000) "Examining International Responses to Illicit Arms Trafficking," Crime Law and Social Change 33:155.

[15] Oxfam,(2016). From Pledge to Commitment. https://www.oxfam.org/sites/www.oxfam.org/ files/bn-carpledge-to-commitment-151116-en_0.pdf,

[16] PM News (10 February 2016). Nigerian Army Arrest Two Soldiers Working with Boko Haram. http:// www.pmnewsnigeria.com/2016/02/10/nigerian-army-arrest-two-soldiers-working-with-bokoharam

[17] See Africa council for Religions Leaders (2006) "Small Arms and Light Weapons: Africa A Resource Guide for Religions for Peace.

[18] Small Arms Survey (2001). Profiling the Problem, (Oxford: Oxford University Press,), p. 197.

[19] Small Arms Survey. (2007). Small Arms Survey: Guns and the City. Oxford: Oxford University Press, 2007. See especially chapters 1-4.

[20] Small Arms Survey (2013), "Weapons and the World: Learning from Africa", Cambridge Reporting, No. 33. August 2013.

[21] Small Arms Survey (2015), "Documenting Small Arms and Light Weapons”, A Basic Guide. Issue Brief, Cambridge, No. 14, July 2015.

[22] Small Arms Survey (2016). The online trade of light weapons in Libya, Dispatch number 6, April 2016. 28

[23] Stohl, R (2017) "United States Weakens Outcome of UN Small Arms and Light Weapons Conference," Arms Control Today, September 2011, pp. 34-35. 14

[24] Stohl, R. and Myescough, R (2007) "Sub-Saharan Small Arms: The Damage Continues," Current History 106: 231.

[25] Taylor, M. (2006), "UN Small Arms Conference Deadlocks," Arms Control Today, September, p. 46.

[26] UNGA (United Nations General Assembly) (2005). Resolution 49/159, adopted 23 December. A/RES/49/ 159 of 24 February 2005.

[27] UNHCR (2017), Regional Strategy for Forced Displaced of Malians: Refuges and Internally Displaced Persons. http://data.unhcr.org/SahelSituation/regional.php

[28] UNIDR (2006), Combating the Proliferation of Small Arms and Light Weapons in West Africa, Handbook for the Training of Armed and Security Forces, United Nations, Geneva, Switzerland Uslaner

[29] United Nations. Programme of Action to Prevent, Combat, and Eradicate the Illicit Trade in Small Arms and Light Weapons in All Its Aspects. UN Doc. A/CONF.192/15, July 20, 2001.

[30] UN Sexual Violence in Conflict. Report on CAR. http://www.un.org/sexualviolenceinconflict/countries/ central-african-republic/

Citation: Osimen, Goddy Uwa, et.al. "The Role of ECOWAS in the Fight against the Proliferation of Small Arms and Light Weapons in West-Africa Sub-Region" International Journal of Political Science (IJPS), vol 6, no.4, 2020, pp. 01-11. doi: https://doi.org/10.20431/2454-9452.0604001.

Copyright: (C) 2020 Authors. This is an open-access article distributed under the terms of the Creative Commons Attribution License, which permits unrestricted use, distribution, and reproduction in any medium, provided the original author and source are credited. 